\title{
Threats and Opportunities of the COVID 19 on Tourism Industry in Sri Lanka and South Asian Region
}

\author{
Upul Jayapriya Senanayake \\ Colombo Faculty of Commerce and Management Studies, University of Kelaniya, Athurugiriya, Sri Lanka
}

\section{Email address:}

seniyas@yahoo.com.sg

\section{To cite this article:}

Upul Jayapriya Senanayake. Threats and Opportunities of the COVID 19 on Tourism Industry in Sri Lanka and South Asian Region. International Journal of Hospitality \& Tourism Management. Vol. 5, No. 1, 2021, pp. 15-20. doi: 10.11648/j.ijhtm.20210501.13

Received: February 6, 2021; Accepted: April 13, 2021; Published: April 23, 2021

\begin{abstract}
Covid 19 Global pandemic has now brought the entire socio-economic structures in to a standstill state all over the world. It has already challenged the global operations of several business sectors. Time has come to rethink how to recover and regain of the economy, employment and business functions with a fresh beginning in most of the worsened economic sectors. South Asia (Bangladesh, Bhutan, India, Pakistan, Nepal, Sri Lanka; Afghanistan and the Maldives) with a population of 1.8 billion has been severely affected by the COVID-19 pandemic due to poor public health infrastructure, pervasive informality and poor coverage of social protection. The key sectors such as MSMEs, tourism and labour-intensive exports such as readymade garments have been most adversely impacted, leading to loss of jobs for the millions of people in the sub-region. The economic growth has come to a grinding halt and the threat of rising incidence of poverty, hunger and inequality is real. This sudden fall in tourism industry have created severe economic and social consequences within and beyond tourism in the region. Sri Lanka is a country with open economy, has hit badly under this circumstances, in particularly the Sri Lankan export market. Sri Lankan Rupee is depreciating and U.S Dollar has increased to Rs.197/= by January 2021. Total export of Sri Lanka in 2019 was \$16.14Bn which comprised \$11.94Bn from Merchandise exports and \$4.2Bn from service sector. The services sector revenue generation was mainly from the tourism industry which amounts to $\$ 3.6 \mathrm{Bn}$ during 2019 . However this was $18 \%$ drop compares to previous year which was $\$ 4.2 \mathrm{Bn}$ in 2018 , following the Easter Sunday attack in April 2019. As a result of Covid - 19 global pandemic outbreaks, many countries imposed travel restrictions and locked down no of cities/countries. Sri Lankan government imposed Island wide curfew on $20^{\text {th }}$ March 2020 resulting tourism industry dropped to the bottom while crippling the Sri Lankan economy. For Sri Lanka, tourism sector's contribution towards countries development is been quite considerable. This paper discuss the present situation, how to recapture the tourism market and to create new opportunities for future growth in this foreign currency earning very important sector in Sri Lanka as well as in South Asian Region.
\end{abstract}

Keywords: Merchandise Exports, Service Exports, Tourism Industry, MICE Industry, Eco Tourism, Ayurvedic Tourism, Per Capita Income (GDP)

\section{Introduction}

Traveling is the most entertaining way to meet strangers and explore new places if the route is free of illness, crime, and catastrophes. However, most of the time, with the right know-how, the risks can be minimized or mitigated, and the travel diaries fill up with unforgettable experiences. Epidemics and pandemics are two of the most frightening news for travelers or planners. In such cases, it may be difficult or impossible to avoid the disease. Besides, not only the travelers but also other people they contact during the journey are at risk. Passengers play a serious role in the transfer of epidemics or pandemics between locations. In recent months, the world is focused on epidemics due to the emergence of a new corona virus [13]".

The COVID-19 pandemic has, with alarming speed, dealt a heavy blow to an already-weak global economy, which is expected to slide into its deepest recession probably after the second world war [1]".

The global travel and tourism industry was estimated to be worth over $\$ 700$ billion in 2020 - and it's now forecast to be dropped to $\$ 447$ billion as a result of the corona virus pandemic. Europe is likely to be particularly hard hit, with predicted revenue dropping from more than $\$ 200$ billion to 
$\$ 124$ Billion. Tourism (including travel, accommodation, food and culture) contributes almost $10 \%$ of EU GDP, while between June and August; EU residents typically make 385 million tourism trips and spend $€ 190$ billion (\$205 billion) [16]".

Economic disruptions are likely to be more severe and protracted in emerging market and developing economies with larger domestic outbreaks and weaker medical care systems; greater exposure to international spillovers through trade, tourism, and commodity and financial markets; weaker macroeconomic frameworks; and more pervasive informality and poverty. Beyond the current steep economic contraction, the pandemic is likely to leave lasting scars on the global economy by undermining consumer and investor confidence, human capital, and global value chains [1]".

The global G.D.P was contributed by $10.3 \%$ from Travel \& Tourism Industry \{World Travel \& Tourism Council (WTTC) $\}$ and also 330 million jobs were connected to the industry in 2019 [16]". The sector has seen high growth in the last decade, which can be largely attributed to factors such as rising disposable incomes, the emergence of low-cost carriers, ease of travel through internet-based services and the relaxation of visa regulations.

The decline in the first ten months of the year represents 900 million fewer international tourist arrivals compared to the same period in 2019, and translates into a loss of US\$ 935 billion in export revenues from international tourism, more than 10 times the loss in 2009 under the impact of the global economic crisis [2]".

In South Asia, WTTC estimates that the sector contributed $\$ 234$ billion or $6.6 \%$ of the region's GDP in 2019 [16]". Within the region, the pandemic could not have come at a worse time for Nepal's tourism industry, which has almost entirely shut down since the outbreak. The government had declared 2020 as the Visit Nepal Year, announcing a national campaign with an annual target of achieving 2 million tourist arrivals. With the country's borders closed to adventureseeking mountaineering crowds, the direct actors along in the tourism value chain (tour operators, trekking agencies, mountain guides and Sherpas) have lost their only source of income [16]". So as India, Thailand, Maldives....etc are being badly affected.

\subsection{In Asia and the Pacific, We Can Distinguish Between Four Groups of Economies [10]":}

(i) Highly tourism-dependent economies, where the direct contribution of tourism to GDP exceeds $10 \%$ : Cambodia; Fiji; Georgia; Hong Kong, China; Maldives; Palau; Thailand; Tonga; Samoa; and Vanuatu [10]".

(ii) Tourism-dependent economies, where the contribution of tourism to GDP ranges from $5 \%$ to $10 \%$ : Armenia, Azerbaijan, the Federated States of Micronesia (FSM), the Kyrgyz Republic, Malaysia, the Marshall Islands, New Zealand, Singapore, Solomon Islands, and Sri Lanka [10]”.

(iii) Economies with major tourism, where tourism accounts for $2.5 \%$ to $5 \%$ of GDP: Australia; Bhutan; the Lao People's Democratic Republic; Mongolia;
Nepal; the Philippines; Taipei, China; Timor-Leste; Uzbekistan; and Viet Nam [10]"

(iv) Economies with minor tourism, less than $2.5 \%$ of GDP: Afghanistan, Bangladesh, Brunei Darussalam, Japan, Kazakhstan, Kiribati, India, Indonesia, Myanmar, Nauru, Pakistan, Papua New Guinea, the People's Republic of China (PRC), the Republic of Korea, and Tajikistan [10]".

\subsection{Impact as a Summary in South Asia}

Bangladesh Impact: US\$2.03 billion potential loss to GDP. Jobs: 420,000 jobs at risk. Sectors: 50 million jobs in informal sector at risk across industries [9]".

India Impact: US\$43.4 billion potential loss to GDP. Jobs: 9 million jobs at risk. Sectors: 60 percent of hotels closed and MICE Market has completely shut down [9]".

Nepal Impact: US\$460 million potential loss to GDP. Visit Nepal Campaign cancelled. Jobs: 230,000 jobs at risk. Sectors: 20,000 tour and trekking guides are unemployed and 2,600 trekking agencies closed [9]'.

Sri Lanka Impact: US\$1.99 billion potential loss to GDP. Jobs: 200,000 jobs at risk. Sectors: Accommodation occupancy rates declined to near zero for hotels outside of Colombo by the end of March. Colombo hotels at 15-20 percent occupancy [9]".

Bhutan Impact: US\$2.2 million lost so far. Jobs: 50,000 jobs at risk with flow on impacts to 150,000 jobs. Sectors: Bhutan Airlines at risk. Supply chain impacted with 85 percent of goods imported from India [9]".

Maldives Impact: US\$700 million potential loss to GDP. Jobs: 35,000 jobs at risk. Sectors: Accommodation occupancy growth rates dropped by -36.7 percent and RevPAR dropped by -53.8 percent in March 2020 compared to March 2019 [9]".

Pakistan Impact: US\$3.64 billion potential loss to GDP. Jobs: 880,000 jobs at risk. Region: Khyber Pakhtunkhwa Province likely to suffer US\$10-20 [9]".

Sri Lanka being a beautiful Island blessed with natural resources, historical and cultural significance and naturally different geographical locations under different climates and environments, Sri Lanka being rank number one popular tourist destination among tourists in 2019 (by Globally recognized company "Lonely Planet"). The growth in tourism industry of Sri Lanka was rapid since the end of 30 year civil war in 2009 [3]". Since then tourism has been a key contributor and become one of the key industry that generates much needed foreign currency to the Sri Lankan economy. In 2009 , there were 448,000 no of tourists arrived to the country. In 2015, the figure was increased to $1,798,380$ showing 300 percent growth and in 2016, number further increased by 14.0 percent and recorded as $2,050,832$. The number of tourists recorded in 2017 was 2,116,407 and it was continuously increased by another 10.3 percent to $2,333,796$ in 2018, the highest recorded number in tourism history. Most of these tourists are from Europe (60\%), Asian Pacific Countries (34\%) and the rest from North and South America as well as from Middle East. The initial projection for 2019 
was 2.5 Million tourists however it was dropped to 1.9 Million due to Easter Sunday tragedy in April 2019. Per capita income also dropped from $\$ 4,079$ to $\$ 3,852$ during this period [4]". Sri Lanka's tourism ministry is aiming to attract four million tourists during 2020 and expected revenue is over $\$ 5.0 \mathrm{Bn}$. However following the COVID 19 viral infection, which was first reported in November 2019 in Wuhan, China and then started to significantly spread across borders, leading the World Health Organization ("WHO") to declare COVID-19 as a global pandemic on $11^{\text {th }}$ March 2020 which compelled Sri Lankan government to suspend the on arrival Visa for tourists on $11^{\text {th }}$ March 2020. It was on $20^{\text {th }}$ March 2020, Sri Lankan government declared Island wide curfew as the outbreak continues to spread. The number of tourist arrivals in Sri Lanka dropped to 71,370 in March 2020. Chinese tourist arrivals in particular suffered a massive drop, down by 92.5 per cent between January and February alone. Unfortunately, with this rapid expansion of the virus, number of infected people now record as nearly 118.6 $\mathrm{Mn}$ and total deaths recorded as $2.63 \mathrm{Mn}$ globally and in South Asian Region 13.76 Million cases and 211,314 deaths. In Sri Lanka it is 86,503 cases reported with 511 deaths (all data as at 11.03.2021) and the numbers are keep increasing. Consequently, traveling has become one of the key contributors of carrying the virus around the globe causing tremendous pressure on international travel and tourism operations including airline industry.

Travel, tourism, hotel and MICE industry (group tourist travel) comes as an umbrella industry, networking with many other sectors in the economy including restaurants, guest houses, community level operations, education, financial, agriculture, medical, transportation, construction, real estate, retail, and vice versa and all these sectors are facing immense challenges at present [5]". This has been remarkable in world history as the most challenging tragedy occurred in the world after decades may be after the World War II. Apart from tourism this has already affected to the retail sector, food, consumer goods, healthcare, delivery, security..etc. This situation needs to be strategically managed with appropriate proactive and reactive measures to overcome the future threats while ensuring the socio - economic well being of all humans allowing space for growth in tourism industry.

\section{Challenges Faced}

Due to the lack of a vaccine and very limited treatment options, non-pharmaceutical interventions occurred to be the primary strategy to contain the pandemic. Unprecedented global travel restrictions and appeals to stay at home have caused the most critical disruptions of the global economy since World War II. Given the international travel bans that affect more than $90 \%$ of the global population and widespread restrictions on public gatherings and community mobility, tourism largely ceased in March 2020. Since the quarantine introduction, millions of jobs in the global tourism sector were lost due to flight, event and hotel cancellations [14]".
The Covid-19 pandemic is leading to a dramatic roll-back of economic progress across South Asia. While the region managed to contain the spread of the virus better than most, the economic impact on the region has been devastating. South Asia is highly integrated into the global economy, both with regard to trade and international travel. After international travel stopped almost entirely in March, the tourism and business travel sectors experienced unprecedented contraction. Many small businesses have closed permanently due to economic losses brought on by Covid-19 lockdowns and travel restrictions. With each passing month, tens of millions more workers are at risk of sliding into poverty, including many in the middle class. As the pandemic drags on, temporary job losses have become permanent, and household incomes have plummeted [12]".

In Sri Lanka, the tourist arrivals dropped by $17.7 \%$ to 207,507 in February 2020 compared to a year earlier, largely affected by the sharp drop in visitors from China with the COVID-19 outbreak. Tour operators and travel agents have flagged that they are reeling from widespread holiday cancellations and forward bookings in Sri Lanka by tourists following the rapid outbreak of COVID-19 [6]"

Considering the challenges face by Sri Lankan tourism industry due to the Covid 19 pandemic, it is proven that Sri Lanka earns much better recognition and reputation than the other countries in the world in controlling Covid 19 by identifying the infected and contracted people, arrangement of quarantine facilities and medical facilities, appliance of personal protective equipment, in handling of airline/sea line passengers at the respective ports, continuation of supply of basic human needs. This has been same even for foreigners while other developed countries announce nonresidents to leave their countries. Government extended visas for foreigners securing them with available facilities..etc. Hence, this situation would be favorable in flourishing Sri Lanka tourism in the future even though it earns losses today. The indirect impact on travel and tourism industry cannot measure easily and definitely is a significant loss in short term as well as long term. Therefore protecting this industry would definitely be a good investment [6]".

According to SLTDA statistics in 2018, 169,003 and 219,484 people were employed as direct and indirect employees respectively by the tourism industry. As of now, a vast majority of these workers are temporarily unemployed due to the closure of hotels and restaurants, airlines, travel agencies, tourist shops, etc. This has made a significance impact on the families who were totally depending on tourism.

There are number of service providers attached to this industry they are; Accommodation Providers, Travel Agencies, Air lines, Ticketing Offices, Tour Guides, Hotel Employees, Professionals, Consultants, Event Coordinators, Food and Restaurants Suppliers, Hand Craft Manufacturers and Transportation Suppliers..etc. Under this situation there are many losses to the industry, resources including human resource and capital resource will impose huge challenges for tourism stakeholders in the months to come due to zero 
income and zero revenue conditions. We will have to witness a certain number of qualified tourism and hospitality employees leaving the industry and joining more stable industries in the short-run. In this current situation they don't receive any income from their tourism products and tourism investors are facing a financial crisis without being able to maintain a sufficient cash flow to pay back debts, to pay salaries and for other essential maintenance work at the properties. In this backdrop issuing debt moratoriums for identified vital sectors including tourism can be identified as an attempt to protect the industry. Therefore it is important to protect these service providers and remain them to cater for the future tourism demand of the country. Otherwise this may lead to reallocating the resources to other industry where tourism industry would face the challenge of finding the new service providers in future.

\subsection{Recovery Process: Rebuilding Consumer Trust and Confidence}

Although the pandemic remains under control in most parts of the region, the unpredictability of infections have largely discouraged authorities from opening up their borders.

However, one part of the world has remained relatively unscathed over the past few months, a rare success story to offer some hope of a return to normality. The countries of mainland South Asia have proved highly effective in dealing with this global pandemic. Whatever the fortunate mix of explaining factors, one thing can be made clear: life in these countries is well on its way to normality. We spoke to our onthe-ground experts to get some insights into the situation in each country [8]".

After four months of lockdown, the Maldives welcomed tourists back to its resorts and hotels, after publishing a comprehensive sector reopening strategy aimed towards building trust and credibility among potential tourists. Minister Imad signals a strong welcome message to the international tourist community: "We welcome back tourists as resorts opened on the 15 th of July 2020. Tourists can be assured that the Government has put into place strict safety and hygiene standards to ensure the safe reopening of the country to tourists from around the world when travel restrictions begin to ease.". In Sri Lanka, 23 ${ }^{\text {rd }}$ January 2021, Bandaranayake International Airport was opened for foreign tourists and first group of tourists arrived from Ukrain under strict health and safety measures. They were undergone the quarantine process and travelled as a Bio Bubble so that risk was minimal. England Cricket Team also arrived in January 2021 to play two test cricket matches, however restricted for the spectator's participation. The England cricketers then moved to India and playing under similar restrictions

\subsection{Respective Government Supports}

Governments in the region has taken following steps support the industry and provided [15]";

1) Cash Grants/Subsidies
2) Wage subsidies

3) Tax rebates/reliefs/extensions

4) Loan/Loan repayment supports

5) Rules alleviation

6) License fee waivers for businesses

7) Fees/bills waivers

8) Training or mentoring incentives/programs

9) Strategic program launch for tourism

10)Tourism communications or crisis task force

11)Repurpose tourism assets for crisis operations

12)Retrain tourism workers to support health crisis

13)Maintain cargo operations of national carriers

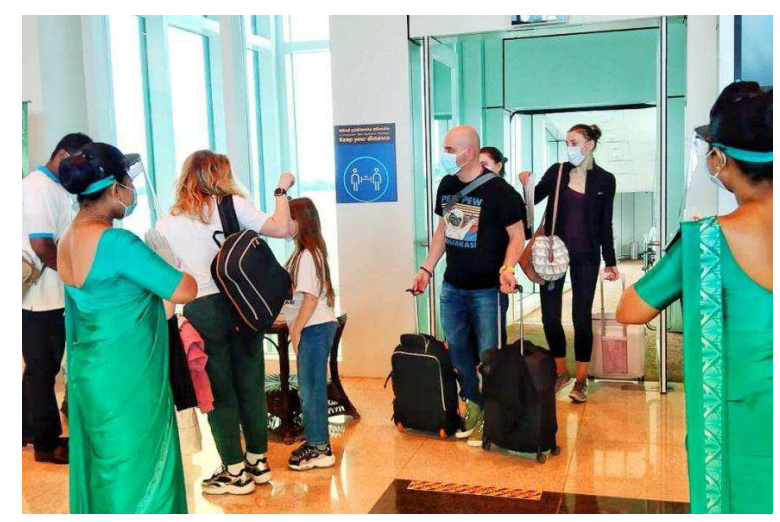

Figure 1. Arrival of Ukraine Tourists to Sri Lanka.

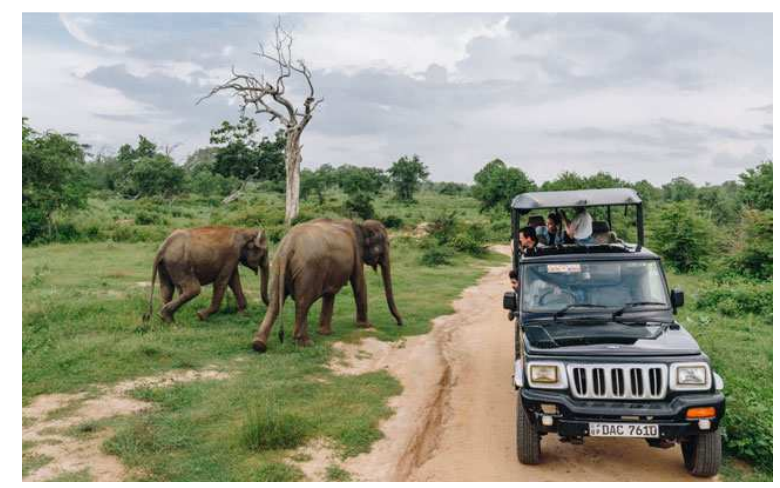

Figure 2. Tourists in Yala Sanctuary - Sri Lanka.

\section{Proposed Recommendations to Overcome the Present Challenges}

To retain the service providers under this situation, it is good to release them from their business loans temporarily, help to retain the employees in their organizations, using the tourism resources like hotels as quarantine centers with a reasonable monthly rental to the organizations.

Once the outbreak is over, hopefully as predict by August 2021, firstly it could be recommended to spread the positive news through news channels and social media platforms to aware the potential tourists and conducting international advertising campaigns as crucial strategies in marketing and promoting Sri Lankan tourism and hospitality industry. At the beginning of re-capturing the market it is utmost important to reduce the hotel and transportation (air, sea and 
ground) fees and also to remove the booking cancellation fees, allowing flexi rates and flexi cancellation policies, allowing for change the booking dates..etc. to be concerned. Considering the pandemic situation tourists are probably concern much on their health and safety. Therefore it is important to concern and carry out proper health and safety procedures at the hotels. Further many Sri Lankan started to re-cultivate in their left out no use lands. Those re-cultivated plantation sites could be converted to Resort Type Remote Eco-Tourism Destinations as they now have cultivated verity of organic foods (Paddy, Vegetables, Fruits, Grains.etc) which could cater for their new resorts. With the social distance mind set, this could create new business opportunities for these plantation owners since the "Eco Tourism" has now become very popular segment in tourism industry all over the world. And also Sri Lanka could promote authentic medical foods and Ayurvedic healing methods (as niche products)as they have positive impact on immunity building to cure this type of epidemic diseases. In fact Ayrvedic tourism going to be a demanding option in near future. Further government will have to initiate tax reduction schemes (for certain period of time) for both micro and macro level business owners and could think of introducing interest-free capital loan schemes and job guarantees for permanent carder employees.

Further, need to initiate a digital platform with the collaboration of World Tourism Organization (UNWTO) to share new ideas and opportunities in the tourism sector. Also national tourism bodies like Sri Lanka Tourism Promotion Bureau (SLTPB), Sri Lanka Tourism Development Authority (SLTDA), Sri Lanka Convention Bureau (SLCB) will have to play a key role by employing a globally driven marketing and branding campaign highlighting the best practices applied in a crisis situation like Covid 19 pandemic. It is important by hoteliers, travel agents to keep a continuous linkage with key customers, checking their safety during the outbreak. Research and development activities need to be encouraged to open up the hidden cornerstones. Domestic travel market will probably grow first compares to the international tourism market as many are suffering from home bound stress. At last but not least all the tourism industry stakeholders need to think about new innovative low cost strategies, making the process more convenient for all the stakeholders once the industry start up again and thinking the first mover advantages as well.

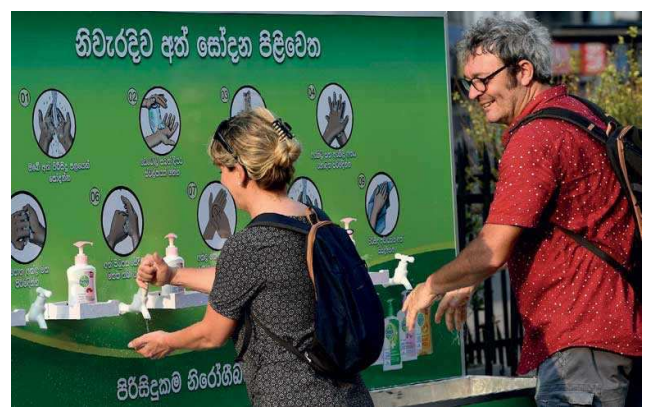

Figure 3. Guidance for Protection against Covid 19 in Sri Lanka.
Some other Asian countries like Vietnam, Laos, Cambodia, Myanmar and Thailand could look at creating travel corridors, travel bubbles between the countries to open for tourists. These countries have proved highly effective in dealing with this global pandemic and seem to have successfully contained the virus, as can be seen through their recent figures [11]".

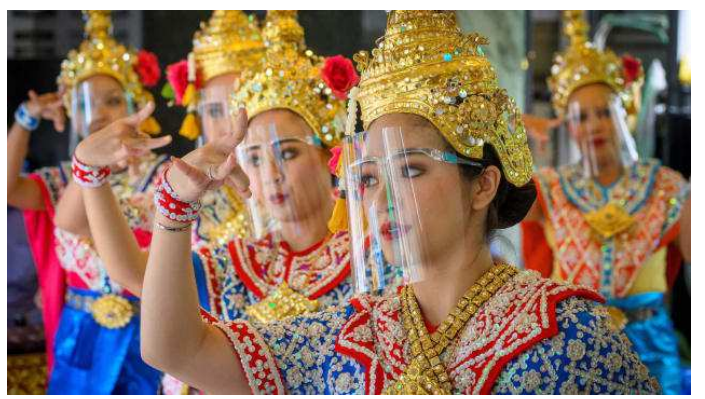

Figure 4. Traditional Thai dancers wearing protective face shields perform at Bangkok's Erawan Shrine, which was reopened after the Thai government relaxed measures to combat the spread of Covid-19 on May 4. [7]'.

In India, they have mainly focused on domestic tourism at post Covid 19 pandemic as many Indians are now interested in traveling to unexplored areas in the country.

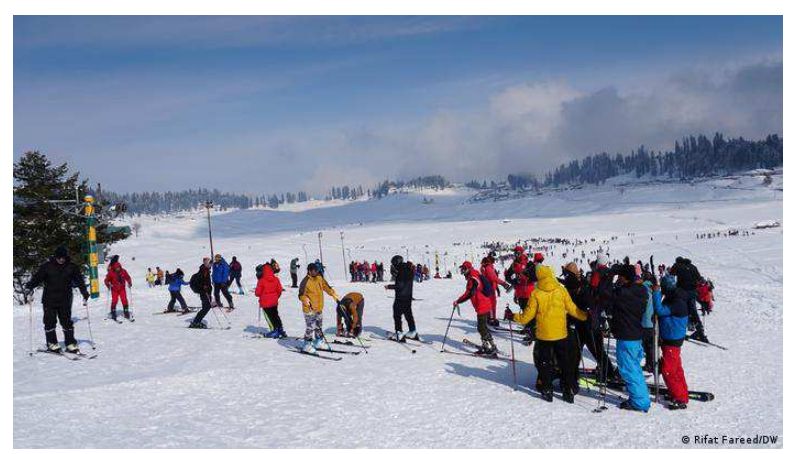

Figure 5. Heavy Influx of Tourist attracted in Kashmir-January 2021.

\section{References}

[1] Open Knowledge repository, June 2020.

[2] United Nations World Tourism Organization, (2020). "Impact assessment of the Covid-19 outbreak on international tourism".

[3] Ranasinghe, R., \& Sugandhika, M. G. P. (2018). "The contribution of tourism income for the economic growth of Sri Lanka".

[4] Daily Fit (April 10 $0^{\text {th }}$ 2020); Strategies for Sri Lanka aim Covid 19 Crisis http://www.ft.lk/front-page/Forward-marchStrategies-for-Sri-Lanka-amid-COVID-19-crisis/44-698718

[5] Ruwan Ranasinghe, Anupama Damunupola, Shamila Wijesundara, Chandi Karunarathna Dhananjaya Nawarathna, Sammani Gamage, Amaya Ranaweera, Ali Abdulla Idroos (April 2020) "Tourism after Corona: Impact of Covid19 Pandemicandway Forward for Hotel and MICE Industry in Sri Lanka”. 
[6] Daily. (2020). Tourism industry meets to assess COVID-19 impact, way forward. http://www.ft.lk/front-page/Tourismindustry-meets-to-assess-COVID-19-impact-way-forward/44696983

[7] The future of tourism in Asia during Corona Virus Era - Julia Hollingsworth and Kocha Olarn, CNN • Updated 13th May 2020 .

[8] "The Success stories from South East Asia Amidst the Global Pandemic" - Discova, September 2020.

[9] COVID-19 AND TOURISM IN SOUTH ASIA Opportunities for sustainable regional outcomes - World bank Report, December 2020.

[10] Reviving Tourism amid the COVID-19 Pandemic - ADB Brief No 150, September 2020 by Matthias Helble and Anna Fink.

[11] CNBC - "Southeast Asia struggles to kick start its battered tourism industry as the pandemic chokes demand" October 2020 by Nessa Anwar.
[12] Enduring the Pandemic: Rapid Survey on the Impact of Covid-19 on MSMEs in the Tourism Sector and Households in Cambodia - Asia Foundation, January 2021.

[13] Impacts of COVID-19 on global tourism industry: A crossregional comparison, Elsevier Public Health Emergency Collection, October 2020 by Naciye Güliz Uğur and Adem Akbiylk.

[14] COVID-19 impact and survival strategy in business tourism market- Humanities and Social Science communications, November 2020, Asad Aburumman.

[15] Regional Collaboration can help South Asian Nations rebuild and Strengthen Tourism Industry, Hartwing Schafer, July 2020.

[16] Travel and tourism recovery: a perspective for South Asia and lessons for other regions in the age of COVID-19; World Economic Forum; 24 Aug 2020 Ritwija Darbari. 